\title{
Personal Data Protection Policy Impact on the Company Development
}

\author{
OLGA YU. GUSEVA \\ Department of Economics \\ State University of Telecommunications \\ 7 Solomenska Street, Kyiv, 03110, UKRAINE
}

INNA O. KAZAROVA

Department of Thermophysics, Molecular Physics and Energy Efficiency, Educational and Scientific

Institute of Computer Physics and Energy

V. N. Karazin Kharkiv National University

4 Svobody Square, 61022, Kharkiv

UKRAINE

ILONA Y. DUMANSKA

Department of International Economic Relations, Faculty of International Relations

Khmelnytskyi National University

11 Instytutska Street, 29000, Khmelnytskyi

UKRAINE

MYKHAYLO A. GORODETSKYY

Indi.vision

23a Pushkinska Street, 01004, Kyiv

UKRAINE

LINA V. MELNICHUK

Department of Management

State University of Telecommunications

7 Solomenska Street, 703110, Kyiv

UKRAINE

VOLODYMYR H. SAIENKO

Department of Innovation Management, Faculty of Economics and Pedagogical

Academy of Management and Administration

18, Mieczysława Niedziałkowskiego, 46020, Opole

POLAND

\begin{abstract}
This research paper deals with identifying the basic prerequisites for the IT companies' development in terms of tightening requirements for personal data protection. The article aimed at assessing the impact of personal data protection policy on the company development through the assessment of the efficiency of the use of intangible assets. The following methods were used in achieving this aim: comparative analysis, the method of horizontal analysis of company performance, correlation and regression analysis, graphical analysis, as well as the method of expert survey of the impact of macro-environmental factors on the company profitability level. It is established that the degree of personal data protection of customers of IT companies directly affects the financial performance of companies and contributes to the development of IT companies. The article proves that poorly developed personal data protection system of Ukrainian companies is related to the regulatory framework of the creation and registration of personal databases. The main world trends in the development of personal data protection were identified through the study of the provisions of international policy frameworks as compared to the legislation of Ukraine. The main area of application of the results obtained by the author are IT companies, in particular in the management of profitability in the context of
\end{abstract}


strengthening the personal data protection. The obtained results are a contribution to scientific achievements in the field of personal data protection and business development for Central European countries. This is primarily due to the novel research objective.

Key-Words: - Personal Data Protection System; Legal Regulation; International Policy Frameworks; Expert Assessment; Macro-Environmental Factors; Profitability.

Received: June 15, 2021. Revised: November 15, 2021. Accepted: December 19, 2021. Published: January 17, 2022.

\section{Introduction}

The widespread use of information and communication technologies (ICT) in economics, politics, and social relations creates the potential for development, while creating information challenges and security threats. The problem of information security of the organization of work of the IT branch companies is actualized. Due to the complexity of the information sphere, information security cannot be provided at the level of individual enterprises and requires intersectoral cooperation and a unified state policy. In recent years, the issue of information security has attracted much attention at the expert, academic and political levels [1].

Companies operating in the technology sector lead the digital economy. They all process large amounts of information. The digital economy allows carrying out billions of operations and transactions by both legal entities and individuals in the field of exchange of ideas, funds, goods or comments [2].

It should also be noted that the modern society lives in the epicenter of the spread of the knowledge society concept, which aims at the data exchange. An example is the availability and development of services through social networks, which consists in the disclosure of confidential data and the exchange of personal (personalized) information. As users of Facebook, Twitter, Instagram, Pinterest and other types of content on the Internet, companies and their customers, as well as other stakeholders not only consume these opportunities, but also become intangible assets for companies that use social networking resources to acquire or create a customer database [3].

The speed of collection and processing, as well as commercialization of information, undermines the credibility of the digital market and the personal data protection. Concerns about the misuse of personal data raise fundamental issues of confidentiality, data ownership. Therefore, the main problem of company development in the context of building effective personal data protection systems is to increase credibility in their activities and the legitimacy of the use of personal data of customers and other groups of stakeholders [4].

The aim of this study is to assess the impact of IT companies' policies on profitability in the context of tightening requirements for personal data protection.

The hypothesis of the study was as follows: the stable company development is influenced by the efficiency of the use (including profitability) of the intangible asset. For the purpose this article, an intangible asset shall mean personal data. We assume that strengthening the personal data protection policy increases the credibility of the company, and hence the growth of intangible assets in the form of personal data of customers [5].

Due to the fact that the problem of security significantly affects all spheres of society for the development of research, it becomes important to identify the specifics of this area. Analysis of the impact of personal data security on enterprise development and the reverse impact of entrepreneurship on personal data protection policy is one of the most important issues of the modern economy. This study thus contributes to the conceptualization of the global information society and information security. Research shows that security issues are embedded in a broader political context and their technological characteristics are largely the product of policies, including international ones. Thus, the scientific relevance is due to the presentation of the conceptualization of the global information society and its impact on policies in the field of personal data protection.

This aim was achieved through the following research objectives:

- determine the impact of investment in personal data protection policy on the growth of trust in IT companies (exemplified by software developers);

- prove or disprove assumptions about the impact of personal data protection policy on the company development through the growth of the profitability of the use of intangible assets;

- prove that the poorly developed personal data protection system in Ukrainian companies is 
connected with the legal regulation of creation and registration of personal databases;

- confirm the need to implement the provisions of international policy frameworks to the legislation of Ukraine by identifying key trends in the development of personal data management.

\section{Literature Review}

The review of research allowed identifying the following main areas of study in the field of personal data protection and their impact on the company development (Table 1):

- optimization of company's business processes in the context of digital transformation [2-9];

- marketing activities and the use of customer personal databases in the context of digitalization [10-20];

- government action and company development in the context of digital transformation of the economy $[8,21,22]$

- theoretical background for the use and their protection of personal data [23-25];
- marketing and analytics of personal data in the context of digitalization of supply chains and creation of value.

It is also important to note the issue of the impact and creation of the digital economy and measures to bridge the gaps which manifest themselves as information asymmetry. For example, [8] identify the following areas for solving these problems:

- development of digital infrastructure;

- development of a highly effective system for identification and protection of personal data;

- development of applications and services;

- formation of competencies in the field of personal data protection of employees of companies for the implementation of international convention policy;

- protection of intellectual property and personal data as a guarantee of innovative development;

- integration of national legislation into global legislation to comprehensively ensure the reliability and security of personal data processing. Such a policy helps to increase investment attractiveness in the international arena.

Table 1. Studies on Digitalization and Digital Transformation of Personal Data Protection Systems, as well as Other Goods and Services Presented in Journals Indexed in International Scientometric Databases (Scopus, WoS)

\begin{tabular}{|c|c|}
\hline Authors & Object of research \\
\hline Natorina (2020) & Optimization of business activity in the context of digitalization \\
\hline Popova et al. (2019) & ncreasing confidence in marketing activities in a digital society \\
\hline Tleppayev (2019) & The impact of digitalization on energy companies \\
\hline Melnyk et al. (2019) & \multirow{2}{*}{$\begin{array}{l}\text { Assessing the impact of disruptive technologies on the business institutions in } \\
\text { developing economies. }\end{array}$} \\
\hline $\begin{array}{l}\text { Pecheranskyi and } \\
\text { Revenko (2019) }\end{array}$ & \\
\hline $\begin{array}{l}\text { Budanov and Aseeva } \\
\text { (2019) }\end{array}$ & $\begin{array}{l}\text { Research of influence of manipulative marketing technologies on application of } \\
\text { data of potential consumers in the context of digitalization }\end{array}$ \\
\hline $\begin{array}{l}\text { Polozhentseva et al. } \\
\text { (2019) }\end{array}$ & $\begin{array}{l}\text { The effects of digitalization and its impact on the business institution in the } \\
\text { context of modern social transformation }\end{array}$ \\
\hline Trusova (2019) & overnment socio-economic policy in the context of digital economy development \\
\hline Mayakov & modern quality management system \\
\hline Victor et al. (2019) & $\begin{array}{l}\text { company pricing in the era of digitalization and consumer behaviour } \\
\text { Poland }\end{array}$ \\
\hline al. (2020) & ownership of Big Data. \\
\hline $\begin{array}{l}\text { Petrenko and } \\
\text { Shevyakova (2019) }\end{array}$ & $\begin{array}{l}\text { The impact of digitalization on the economy and management of business } \\
\text { institutions }\end{array}$ \\
\hline $\begin{array}{l}\text { Kuznetsova et al. } \\
(2019)\end{array}$ & $\begin{array}{l}\text { Development of human capital as the main driving force of innovative economic } \\
\text { development }\end{array}$ \\
\hline Mexmonov (2020) & $\begin{array}{l}\text { Development of e-commerce and use of customer personal data in the context of } \\
\text { digitalization }\end{array}$ \\
\hline $\begin{array}{l}\text { Bilozubenko et al. } \\
(2020)\end{array}$ & $\begin{array}{l}\text { Analysis of different approaches to the development of the digital economy. } \\
\text { Discovering the nature of digital economic transformation }\end{array}$ \\
\hline Shen et al. (2020) & $\begin{array}{l}\text { Marketing in social networks of IT service companies: analysis involving the } \\
\text { approach to obtaining personal data }\end{array}$ \\
\hline
\end{tabular}




\section{Hung, He and Shen Big Data analytics in the supply chain.}

(2020)

Source: [7-9, 17-20, 23-25, 27-33]

A separate aspect of personal data digitalization is the study of building business processes and mechanisms for the personal data use. Every company must have effective mechanisms for monitoring and managing internal processes. This allows not only to effectively organize production processes, but also to respond quickly to problematic issues.
On the other hand, personal data management is also a subject of improvement and close attention for the spread of digitalization. This is evidenced by the opinion of practitioners, which was expressed in 2016 at the Strategic Policy Forum on Digital Entrepreneurship [26]. Figure 1 illustrates the main needs and business processes that require improvement in the implementation of information technology in the context of digitalization.

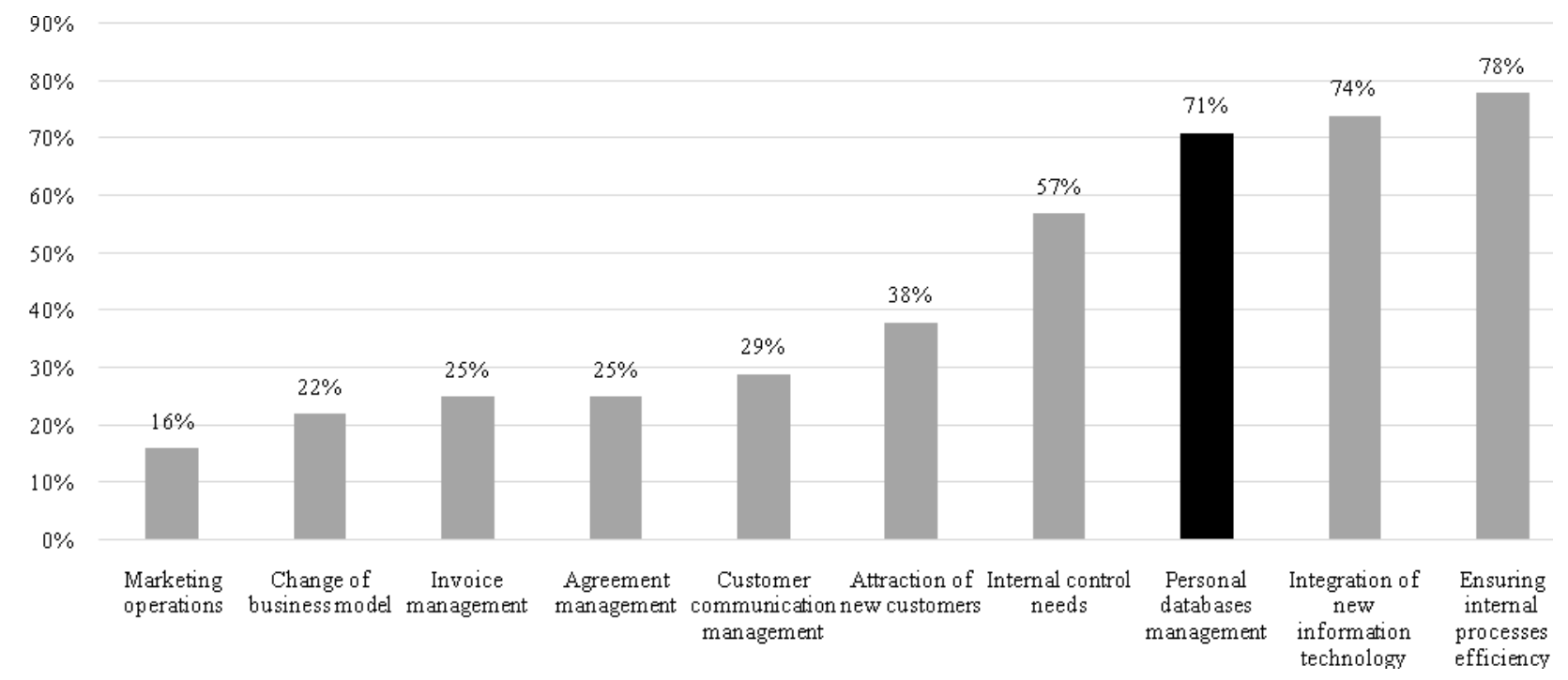

Fig. 1: Ranking of Business Process Areas that Require Improvement

Summing up the review of recent publications, we can conclude that the issues of the impact of the personal data protection system development on the company profitability, its overall financial and property status remain insufficiently covered. Given that the system of personal data protection is a company's intangible asset, it is advisable to consider it from the standpoint of effective asset management.

\section{Materials and Methods}

On the one hand, the study is based on the analysis of the impact of macro-environmental factors on the companies' activities, and on the other - the impact of management efficiency of personal data protection as company's intangible asset on the company profitability. The study was conducted in two stages:
Stage 1. Comparative analysis of the requirements of the national legal framework with the provisions of international policy frameworks.

Stage 2. Assessment of the impact of personal data protection on companies' profitability.

2.1. Ten IT companies operating in the Ukrainian and global IT services markets were selected. They had approximately the same number of employees and of financial performance. In particular, the sample of the study consisted of the following IT companies: Ciklum, NIX, Evoplay, DataArt, Infopulse Ukraine, ZONE3000, Ajax Systems, ELEKS, Intellias, Genesis.

2.2. The data of the officially published annual financial statements of the companies selected for the study, which are prepared in accordance with the international financial reporting standards (hereinafter - "IFRS") were analysed;

2.3. The dynamics of changes in the profitability of the selected enterprises for the study is analysed; 
2.4. The dependence of the use of customer personal data of IT companies and the amount of profit of IT companies is determined.

2.5. Predicted values indicating the efficiency of intangible assets (personal data) use of selected IT companies are built.

To study the impact of personal data protection policy on the company development, we selected the following methods: the methods of horizontal analysis of companies' performance in the IT sector in the dynamics of three years, the method of correlation and regression analysis to determine the relationship between customer personal of the studied IT companies and companies' development data, as well as graphical analysis to determine the specification of the required regression model of data dependence and visual representation of indicators illustrating the efficiency of using intangible assets of IT companies in the form of customer personal data. An expert method of assessing the impact of macro-environmental factors on the companies' profitability was also used.

Let's identify the main aspects of the application of the latter method (expert method):

1. Expert assessment was conducted by interviewing 5 experts from the companies of the study group;

2. The method of expert assessment was questionnaire-based.

3. Scores and their normative value in the study were calculated using the Fishburne rule.

4. Table 2 provides the normative values of assessments of the impact of macro-environmental factors on the companies' activities in the selected industry, which were proposed to experts to apply.

Table 2. Normative Values of the Expert Assessment Scale

\begin{tabular}{|l|l|}
\hline \multicolumn{1}{|c|}{ Assessment items } & \multicolumn{1}{c|}{ Assessment values range } \\
\hline $\begin{array}{l}\text { Importance for the } \\
\text { industry }\end{array}$ & $\begin{array}{l}\text { From 1 to 3; 1 - the lowest importance of the factor's impact on the relevant } \\
\text { field; 3-the highest importance. }\end{array}$ \\
\hline Impact degree & $\begin{array}{l}\text { From 0 to 3; 0 - the lowest impact of the factor on the relevant field; 3 - the } \\
\text { highest impact. }\end{array}$ \\
\hline Nature of the impact & $\begin{array}{l}\text { Experts determine it as positive or negative (quantitative assessment of the } \\
\text { previous items becomes positive or negative) }\end{array}$ \\
\hline Impact assessment & Summation of all received points. Value range: (-6) to (+6). \\
\hline
\end{tabular}

\subsection{Research Limitations}

Given that the study aims to identify the type of relationship between the functioning of the personal data protection system in the company and its profitability, one of the assumptions is that the personal data protection system is the company's intangible asset. In view of the above, the personal data protection system is considered from the standpoint of asset management: the effectiveness of the personal data protection system and the impact on the level of profitability of the selected companies. This necessitates an intermediate stage of research aimed at confirming and identifying signs of personal data as companies' separate asset in modern business conditions. The aim of the study and the hypothesis necessitate the analysis of policy frameworks issued by international organizations, which determine the strategic guidelines for the digital development of personal data and its implications for businesses. The limitations of the study were due to the objective factor of insufficient data on companies, which would contribute to a comprehensive analysis of economic activity and identify correlations with data protection. These restrictions are established by law and are aimed at protecting trade secrets. Disclosure of some issues of internal organization of production would be contrary to ethical principles. The research must meet both the requirements of the law and the principles of academicity and ethics.

\section{Results}

Modern society has undergone significant changes as a result of the rapid digital transformation. Technological innovations have brought a new reality to the anthropology of everyday life - digital. Digitalization of communications and information has given rise to a large number of methods of data exchange. People share details about their location, their mood and their activities on many platforms.

Digital culture emerges in the digital space and masters its features: it is virtual, communication processes in it are accelerated at times, the time of information exchange in it is reduced to minutes. Despite the fact that digital culture involves the transition of man to a new level of knowledge of the world through digital technology, in fact, man is becoming a target in the global world. The amazing paradox of digital culture is its hypocrisy: 
on the one hand the living world, on the other the technological world. And in this world, everyone strives to protect their personal data.A separate aspect of digitalization is the issue of data protection and the impact of regulatory requirements on the companies' activities through the creation of conditions for the protection of customer personal data.
Peculiarities of administration and regulation of the personal data protection system show that the lack of regulation by the state will lead to the development of the shadow economy and the lack of an institutional framework for ensuring an effective system of personal data protection (Table 3 ).

Table 3. Regulatory and Legal Support of the Personal Data Protection System

\begin{tabular}{|c|c|}
\hline Source & Content \\
\hline $\begin{array}{c}\text { African Commission } \\
\text { on Human and } \\
\begin{array}{c}\text { Peoples' Rights } \\
(2013,2016,2019)\end{array}\end{array}$ & $\begin{array}{c}\text { Personal data is any information concerning the person (personal data subject), } \\
\text { including his/her full name, year, month, date and place of birth, address, family, } \\
\text { social, property status, education, profession, income, other information. Legal } \\
\text { remedies for personal data protection include administrative and judicial instruments } \\
\text { to restore the violated right to personal data protection. }\end{array}$ \\
\hline $\begin{array}{c}\text { EU General Data } \\
\text { Protection } \\
\text { Regulation (GDPR) }\end{array}$ & $\begin{array}{c}\text { One of the main areas of legislation is to ensure transparency and accountability to } \\
\text { minimize the risks of individuals' data misuse. It also imposes obligations and } \\
\text { additional burdens on businesses by regulators. }\end{array}$ \\
\hline $\begin{array}{c}\text { Law of Ukraine "On } \\
\text { Personal Data } \\
\text { Protection" dated } \\
01.06 .2010\end{array}$ & $\begin{array}{c}\text { The composition of personal data and the requirement for mandatory registration of } \\
\text { personal databases owned by enterprises are determined. Practice shows that the most } \\
\text { common types of personal databases of Ukrainian companies are: databases of } \\
\text { personal data of employees and personal databases of customers or other contractors. } \\
\text { The reports with information about individuals who were part of the databases are not } \\
\text { subject to registration as an object of personal databases. }\end{array}$ \\
\hline
\end{tabular}

Source: [35-39]

In order to identify global trends and tendencies, we will also consider other analytical reviews and documents issued by international organizations.
Table 4 summarizes the main topical issues of development of systems of protection and counteraction to illegal use of personal databases.

Table 4. Trends in the Development of Systems to Protect and Combat the Illegal Use of Personal Databases

\begin{tabular}{|c|c|}
\hline Source & Covered issues \\
\hline $\begin{array}{c}\text { 2019 UN } \\
\text { Economy } \\
\text { Report }\end{array}$ & $\begin{array}{c}\text { Protecting personal data is a way to help platform users to balance the power of global digital } \\
\text { platforms. This approach gives the latter ownership of their data and the ability to sell (or not } \\
\text { sell) it. }\end{array}$ \\
& $\begin{array}{c}\text { A separate issue here is the formal and informal creation of user personal databases by } \\
\text { companies. In the UN report, increasing confidence in data was seen as a tool for recognizing the } \\
\text { purely collective nature of data value. Instead of individualizing ownership, data companies seek } \\
\text { to build trust between different stakeholders (individuals, businesses, governments) so that they } \\
\text { can share data freely and openly with each other. This can take the form of a recurring } \\
\text { framework aimed at building trust between those who store data and those who need the data; } \\
\text { and can be a more permanent organizational structure with an established management } \\
\text { mechanism. }\end{array}$ \\
\hline OECD & $\begin{array}{c}\text { The growing interaction between personal data, algorithms and big data analytics, related things } \\
\text { and people opens up new huge opportunities. But they also raise questions about data } \\
\text { management at the national and international levels. These include issues of data availability, } \\
\text { accessibility, usability, integrity and security management, as well as concerns about ownership, } \\
\text { implications for trade and competition, as well as for privacy, and so on. The government's } \\
\text { political bodies are struggling with these issues. The use of digital technologies and data is at the }\end{array}$ \\
\hline
\end{tabular}


heart of the digital transformation in all sectors of the economy and society, which means that any policy decision on data can have far-reaching implications.

Source: [40-41].

A separate problem of company development in the context of the personal data protection systems development is to determine the value and recognition of personal data as a separate intangible asset. However, the value of personal data is quite difficult to determine. UN officials believe that personal data should be considered a public resource [40]. This would mean that data collected within a particular jurisdiction must first belong to that jurisdiction, even if the authorities are unable to extract, collect, store or analyse the data.

The rights to control over access, copying, use and deletion of data - fundamental rights related to the concept of "personal data ownership" - are currently affected by different legal frameworks, such as copyright and related rights, or in the case of personal data - the Privacy Framework [41].
As a summary, we can conclude that, the development of personal data protection systems in Ukraine requires additional work to consider in advance the ownership of data and its implications for policy, which will also lead to additional restrictions and administrative burdens for businesses. Figure 2 contains the main proposals for consideration when generalizing the results of the comparative analysis of the institutional environment in Ukraine in the field of personal data protection and the positions of international organizations. At the second stage of our study, we obtained data on the activities of the studied IT companies from open sources and specialized Internet resources (Table 5). Based on these data, we can calculate the efficiency of intangible assets by companies, namely the profit per customer (Table 6).

Data are transferred to third parties or become public property only in the case of voluntary and conscious activity of the subject of information possession.

Data can be legally monitored, with records of users' activity - as opposed to the data they provide (e.g., browsing settings, location data when using cell phones, or phone usage behaviour)

data can be derived from the analysis of personal data (for example, credit scores can be calculated based on a number of factors relevant to a person's financial history). Personal data can also be inferred from anonymous data

Fig. 2: The Directions Identified by the OECD to Be Taken Into Account in Ukrainian Practice

Table 5. Initial Data for the Analysis of the Impact of Personal Data Protection Policy on the Company Development

\begin{tabular}{|l|l|l|l|l|l|l|l|l|l|l|}
\hline \multirow{3}{*}{$\begin{array}{l}\text { Item } \\
\text { No. }\end{array}$} & Company & \multicolumn{3}{|l|}{$\begin{array}{l}\text { Number of specialists inNet profit of the Number of customers of the } \\
\text { Ukraine, persons }\end{array}$} \\
\cline { 3 - 11 } & 2017 & 2018 & 2019 & 2017 & 2018 & 2019 & 2017 & 2018 & 2019 \\
\hline
\end{tabular}




\begin{tabular}{|c|c|c|c|c|c|c|c|c|c|c|}
\hline \multirow{2}{*}{$\begin{array}{l}\text { Item } \\
\text { No. }\end{array}$} & \multirow{2}{*}{ Company } & \multicolumn{3}{|c|}{$\begin{array}{l}\text { Number of specialists } \\
\text { Ukraine, persons }\end{array}$} & \multicolumn{6}{|c|}{$\begin{array}{l}\text { in Net profit of the Number of customers of the } \\
\text { company, thousand UAH company, firms/persons }\end{array}$} \\
\hline & & 2017 & 2018 & 2019 & 2017 & 2018 & 2019 & 2017 & 2018 & 2019 \\
\hline 1 & Ciklum & 2,654 & 2,692 & 2,725 & $2,937.4$ & $8,505.5$ & 4,723 & 845 & 1,023 & 1,207 \\
\hline 2 & NIX & 2,136 & 2,271 & 2,390 & 302.3 & 968.6 & $1,856.3$ & 712 & 845 & 1,063 \\
\hline 3 & Evoplay & 1,963 & 2,050 & 2,188 & $1,254.9$ & $1,063.7$ & $1,745.3$ & 516 & 678 & 701 \\
\hline 4 & DataArt & 1,741 & 1,900 & 2,100 & 632.5 & $1,258.6$ & $1,512.3$ & 469 & 763 & 1,012 \\
\hline 5 & $\begin{array}{l}\text { Infopulse } \\
\text { Ukraine }\end{array}$ & 1,875 & 1,940 & 1,991 & 103.6 & 569.7 & $1,012.6$ & 230 & 450 & 780 \\
\hline 6 & ZONE3000 & 1,598 & 1,640 & 1,815 & 136.8 & 489.7 & 986.7 & 196 & 374 & 500 \\
\hline 7 & Ajax Systems & 602 & 900 & 1,600 & 405.8 & 596.7 & 963.7 & 230 & 310 & 450 \\
\hline 8 & ELEKS & 1,478 & 1,514 & 1,594 & 236.8 & 471.3 & 693.8 & 241 & 413 & 493 \\
\hline 9 & Intellias & 1,489 & 1,510 & 1,570 & 196.7 & 397.4 & 854.3 & 180 & 270 & 390 \\
\hline 10 & Genesis & 1,475 & 1,528 & 1,536 & 296.7 & 487.6 & 798.3 & 150 & 280 & 370 \\
\hline
\end{tabular}

Table 6. Analysis of the Effectiveness of Using Intangible Assets of the Studied IT Companies, Thousand

\begin{tabular}{|l|l|c|c|c|c|}
\hline Item No. & \multicolumn{1}{|c|}{ Company } & $\mathbf{2 0 1 7}$ & $\mathbf{2 0 1 8}$ & $\mathbf{2 0 1 9}$ & Deviation 2019 to 2017 \\
\hline 1 & Ciklum & 3.48 & 8.31 & 3.91 & 0.44 \\
\hline 2 & NIX & 0.42 & 1.15 & 1.75 & 1.32 \\
\hline 3 & Evoplay & 2.43 & 1.57 & 2.49 & 0.06 \\
\hline 4 & DataArt & 1.35 & 1.65 & 1.49 & 0.15 \\
\hline 5 & Infopulse Ukraine & 0.45 & 1.27 & 1.30 & 0.85 \\
\hline 6 & ZONE3000 & 0.70 & 1.31 & 1.97 & 1.28 \\
\hline 7 & Ajax Systems & 1.76 & 1.92 & 2.14 & 0.38 \\
\hline 8 & ELEKS & 0.98 & 1.14 & 1.41 & 0.42 \\
\hline 9 & Intellias & 1.09 & 1.47 & 2.19 & 1.10 \\
\hline 10 & Genesis & 1.98 & 1.74 & 2.16 & 0.18 \\
\hline
\end{tabular}

Thus, as the studied indicators show, the level of efficiency of using intangible assets of IT companies has increased for all companies over the past three years. At the same time, the highest absolute growth rates are observed in NIX, ZONE3000, Intellias and others. Among the surveyed IT companies, Ciklum (UAH 3.91 thousand/customer as of 2019), Evoplay (UAH 2.49 thousand/customer) and Intellias (UAH 2.19 thousand/customer company) have the highest level of efficiency of using intangible assets in the form of personal customer data (Figure 3). The figure shows that Ciklum uses intangible resources most efficiently. All other market participants who participated in the study are at the average level of use of intangible resources. This is primarily due to the low information culture that is inherent in economies that are moving from industrial to digital. According to the results of the analysis using the Trend Equation tool in Excel, we obtained the following regression coefficients and elasticity coefficients (Table 7).

Thus, at the stage of specification we chose a third degree polynomial model (Figure 4). It was found that in the studied situation $93.2 \%$ of the total variability $\mathrm{Y}$ is explained by the change of $\mathrm{X}$. It was also found that the parameters of the model are statistically significant (Fcalc.> Fcrit, $13.70588235>4.102821)$. 
WSEAS TRANSACTIONS on ENVIRONMENT and DEVELOPMENT DOI: $10.37394 / 232015.2022 .18 .25$
Olga Yu. Guseva, Inna O. Kazarova, Ilona Y. Dumanska, Mykhaylo A. Gorodetskyy, Lina V. Melnichuk, Volodymyr H. Saienko
We will forecast the net profit and efficiency of intangible assets of the surveyed IT companies in 2021 based on the use of the developed model, provided sustainability of the personal data protection policy of the surveyed IT companies (Table

$8)$.

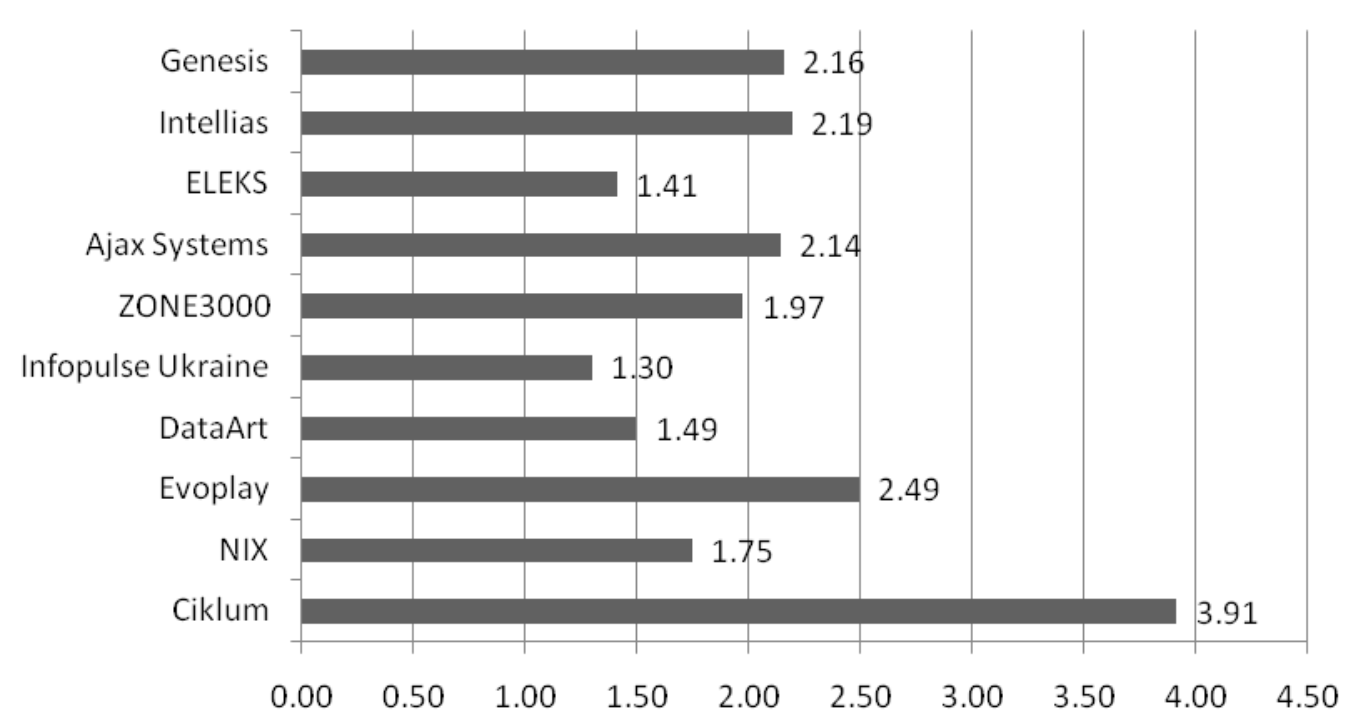

Fig. 3: Indicator of the Efficiency of Using Intangible Assets of the Surveyed IT Companies As of 2019, UAH Thousand/Customer

Table 7. Summary Indicators of Regression Models to Determine the Dependence of IT Company Development Indicators on the Degree of Customer Personal Data Protection and the Corresponding Forecasting

\begin{tabular}{|l|l|c|c|c|}
\hline \multicolumn{1}{|c|}{ Form of trend } & \multicolumn{1}{|c|}{ Trend equation } & $\begin{array}{c}\text { Correlation } \\
\text { coefficient r }\end{array}$ & $\begin{array}{c}\text { Coefficient of } \\
\text { determination } \mathbf{R}^{\mathbf{2}}\end{array}$ & $\begin{array}{c}\text { F-test } \\
\text { r R2 F }\end{array}$ \\
\hline Linear & $\mathrm{y}=3,0462 \mathrm{x}-604,88$ & 0.77711003 & 0.6039 & 0.381153749 \\
\hline Exponential & $\mathrm{y}=410, \mathrm{e}^{0,0016 \mathrm{x}}$ & 0.86608314 & 0.7501 & 3.00160064 \\
\hline Logarithmic degree & $\mathrm{y}=1974,1 \mathrm{n}(\mathrm{x})-11238$ & 0.71944423 & 0.5176 & 1.072968491 \\
\hline $\begin{array}{l}\mathrm{y}=0,0082 \mathrm{x}^{2}-9,594 \mathrm{x}+ \\
\text { pecond }\end{array}$ & 0.88741197 & 0.7875 & 3.705882353 \\
\hline Third degree polynomial & $\begin{array}{l}\mathrm{y}=0,0000 \mathrm{x}^{3}-0,0661 \mathrm{x}^{2}- \\
44,3404 \mathrm{x}-8399,7525\end{array}$ & 0.96540147 & 0.932 & 13.70588235 \\
\hline Power & $\mathrm{y}=1,1601 \mathrm{x}^{1,0828}$ & 0.8286133 & 0.6866 & 2.190810466 \\
\hline
\end{tabular}

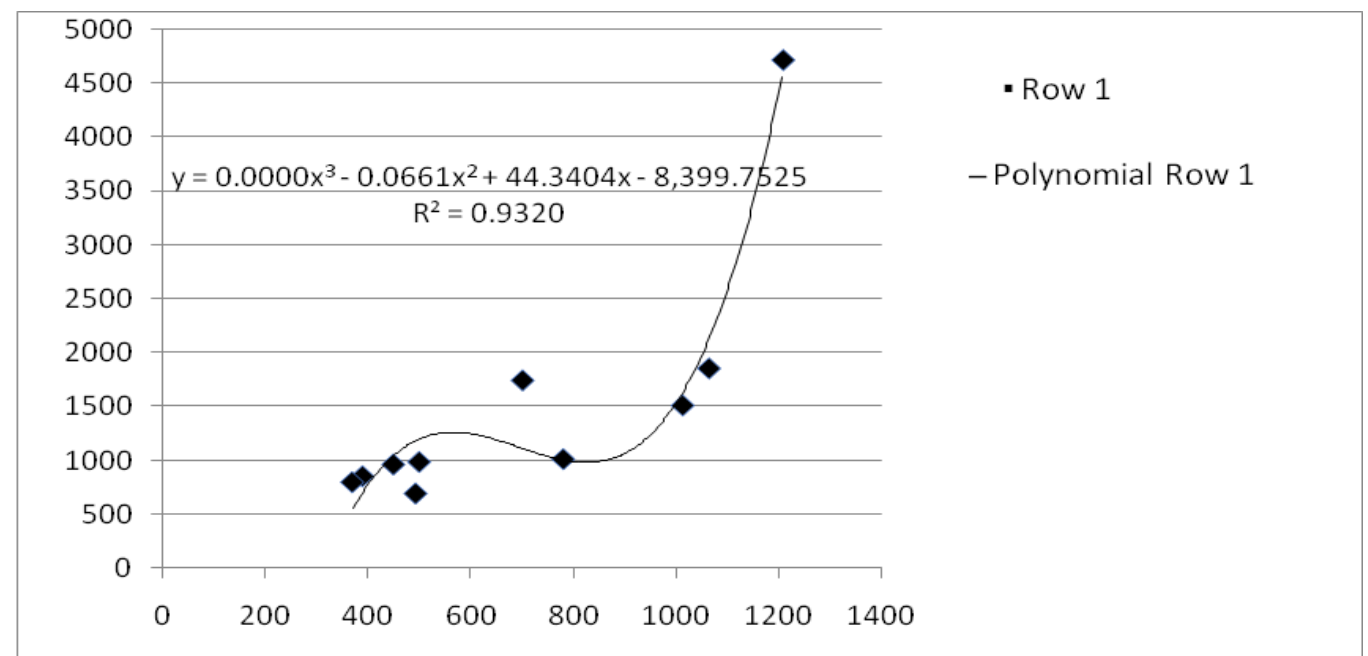

Fig. 4: Dependence of the Use of Customer Personal Data of IT companies and the Profit of IT Companies 
Table 8. Forecast Values of the Efficiency of Intangible Assets of the Studied IT Companies, Thousand $\mathrm{UAH} /$ Firm in 2021

\begin{tabular}{|l|l|l|l|l|}
\hline $\begin{array}{c}\text { Item } \\
\text { No. }\end{array}$ & Company & $\begin{array}{c}\text { Number of customers } \\
\text { of the company, } \\
\text { firms/persons }\end{array}$ & $\begin{array}{c}\text { Net profit of } \\
\text { the company, } \\
\text { thousand UAH }\end{array}$ & $\begin{array}{c}\text { The efficiency of intangible } \\
\text { assets of the surveyed IT } \\
\text { companies in the forecast 2021 }\end{array}$ \\
\hline 1 & Ciklum & 1,207 & 4723 & 4.32 \\
\hline 2 & NIX & 1,063 & $1,856.3$ & 1.98 \\
\hline 3 & Evoplay & 701 & $1,745.3$ & 2.71 \\
\hline 4 & DataArt & 1,012 & $1,512.3$ & 1.69 \\
\hline 5 & $\begin{array}{l}\text { Infopulse } \\
\text { Ukraine }\end{array}$ & 780 & $1,012.6$ & 1.56 \\
\hline 6 & ZONE3000 & 500 & 986.7 & 2.13 \\
\hline 7 & Ajax Systems & 450 & 963.7 & 2.54 \\
\hline 8 & ELEKS & 493 & 693.8 & 2.00 \\
\hline 9 & Intellias & 390 & 854.3 & 2.59 \\
\hline 10 & Genesis & 370 & 798.3 & 2.60 \\
\hline
\end{tabular}

Let's clearly show the comparative volumes of forecast values of the efficiency of use of intangible assets of the studied IT companies in 2019 and 2021 (Figure 5).

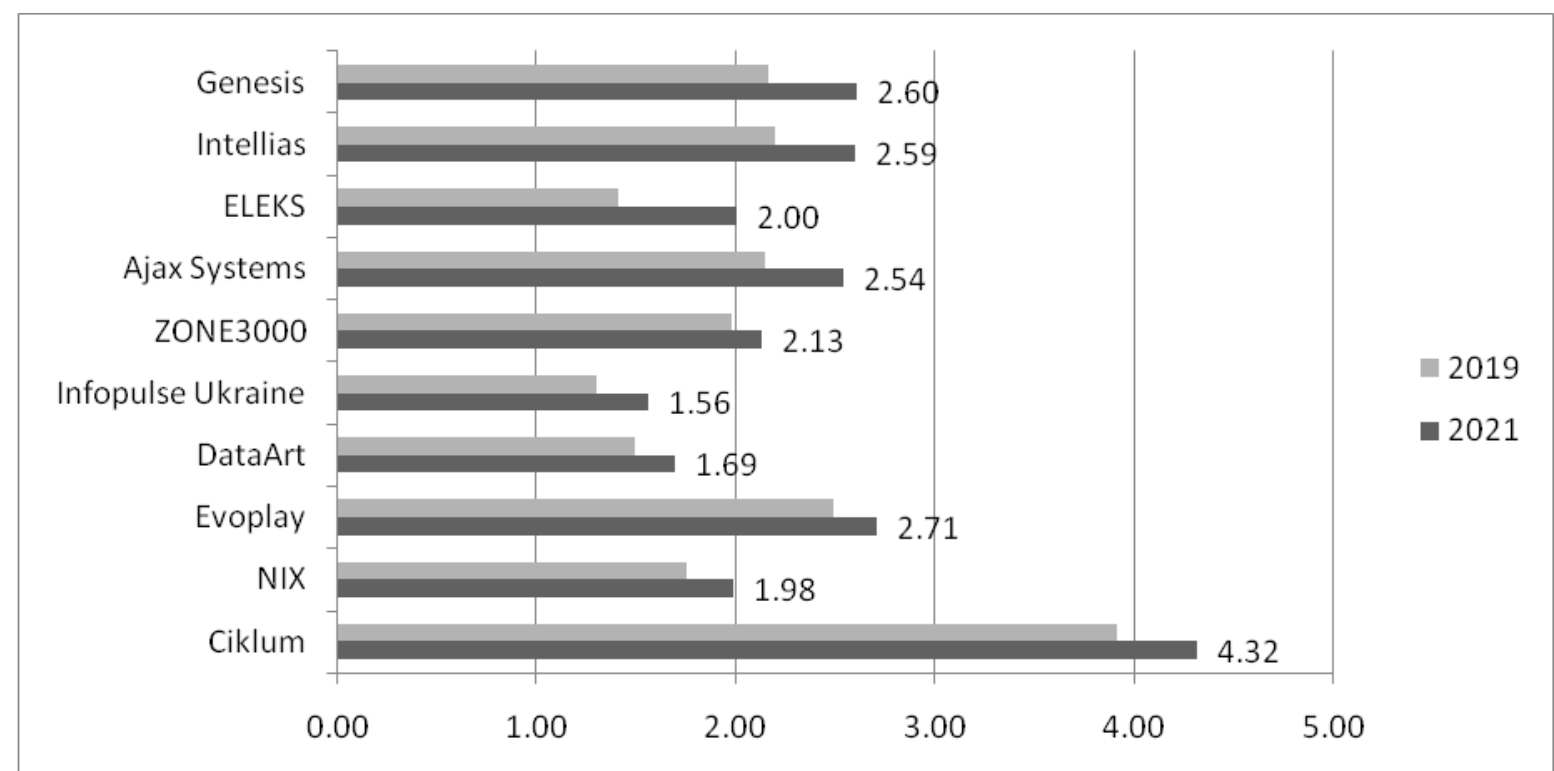

Fig. 5: Comparative Values of the Indicator of Efficiency of Intangible Assets of the Selected IT Companies in 2019 and in 2021, Thousand UAH/Customer

Therefore, we see an increase in the efficiency of intangible assets of surveyed IT companies in 2021. Such growth will be economically justified if continued investment in the customer personal data protection of surveyed IT companies, which will strengthen customer confidence and increase their number.

The obtained data and tendencies, as well as the dynamics of change of profitability of studied companies, serve as a basis for carrying out an expert assessment of influence of a macroenvironment. Initial conditions for expert observation:
1. Identification of macro-environmental factors that have a direct or indirect impact on the level of profitability of IT companies;

2. Determining the priority of each individual factor of the macroenvironment (at the sectoral level, the degree of importance and the nature of the impact);

3. Determining the cumulative impact of macro-environmental factors on the level of profitability of the studied enterprises. Table 9 shows the main results of the assessment of the impact of certain macro-environmental factors conducted by 5 experts. 
Table 9. Assessment of the Impact of the Macroenvironment on the Profitability of IT Companies

\begin{tabular}{|c|c|c|c|c|c|}
\hline Experts & Macro-environmental factors & $\begin{array}{c}\text { Importan } \\
\text { ce for the } \\
\text { industry } \\
(1,2,3)\end{array}$ & $\begin{array}{c}\text { Degree of } \\
\text { influence } \\
\text { (from } 0 \\
\text { to 3) }\end{array}$ & $\begin{array}{c}\text { The } \\
\text { nature } \\
\text { of the } \\
\text { impact } \\
(+/-)\end{array}$ & $\begin{array}{c}\text { Impact } \\
\text { assessment }\end{array}$ \\
\hline \multirow[t]{4}{*}{ Expert 1} & Political instability & 2 & 2 & - & -4 \\
\hline & Political situation in the country & 2 & 2 & - & -4 \\
\hline & Cooperation with EU countries & 1 & 2 & + & +3 \\
\hline & $\begin{array}{l}\text { Increased cost of personal data protection due } \\
\text { to the tightening of legislation in this area }\end{array}$ & 3 & 1 & + & +4 \\
\hline \multirow[t]{4}{*}{ Expert 2} & Political instability & 3 & 2 & - & -5 \\
\hline & Political situation in the country & 2 & 3 & - & -5 \\
\hline & Cooperation with EU countries & 1 & 2 & - & -3 \\
\hline & $\begin{array}{l}\text { Increased cost of personal data protection due } \\
\text { to the tightening of legislation in this area }\end{array}$ & 3 & 1 & + & +4 \\
\hline \multirow[t]{4}{*}{ Expert 3} & Political instability & 2 & 2 & - & -4 \\
\hline & Political situation in the country & 3 & 3 & + & +6 \\
\hline & Cooperation with EU countries & 3 & 2 & - & -5 \\
\hline & $\begin{array}{l}\text { Increased cost of personal data protection due } \\
\text { to the tightening of legislation in this area }\end{array}$ & 3 & 1 & + & +4 \\
\hline \multirow[t]{4}{*}{ Expert 4} & Political instability & 3 & 3 & - & -6 \\
\hline & Political situation in the country & 3 & 3 & - & -6 \\
\hline & Cooperation with EU countries & 1 & 2 & + & +3 \\
\hline & $\begin{array}{l}\text { Increased cost of personal data protection due } \\
\text { to the tightening of legislation in this area }\end{array}$ & 3 & 1 & + & +4 \\
\hline \multirow[t]{4}{*}{ Expert 5} & Political instability & 2 & 2 & - & -4 \\
\hline & Political situation in the country & 3 & 3 & - & -6 \\
\hline & Cooperation with EU countries & 1 & 2 & + & +3 \\
\hline & $\begin{array}{l}\text { Increased cost of personal data protection due } \\
\text { to the tightening of legislation in this area }\end{array}$ & 3 & 3 & - & -6 \\
\hline
\end{tabular}

Note: the expert assessment was conducted through a survey of experts from the studied companies.

Based on the expert assessments presented in Table 9 , it can be concluded that the greatest positive impact on the development of the IT industry has cooperation with EU countries. There is also a positive impact on the increased costs of personal data protection due to the strengthening of legislation in this area. This policy improves the perception of the industry in the international market, and thus improves investment attractiveness.

The obtained average value of expert assessments for such a factor of the macroenvironment as "Increased cost of personal data protection due to the tightening of legislation in this area" is +2 . That is, according to most experts, this relevant factor has a direct impact on changing 
the companies' profitability of moderate importance for the industry and the degree of impact.

Therefore, the impact of regulatory requirements that determine the development and strengthening personal data protection systems as intangible assets of companies, have a direct impact on the results of their financial and economic activities.

\section{Discussions}

The development of the business institution in the context of digitalization of personal data protection is the subject of active scientific discussions.

Comparing the methodology of this study and the methodology used by the OECD [42] in assessing the prospects for economic and personal data development, we note that both studies have similar architectonics, but this paper focuses on such an aspect of digitalization of personal data protection as its impact on businesses and the nature as a separate company asset. Significance and scientific novelty in comparison with existing approaches to the study of the impact of personal data protection in the company in its development level, is in particular the study of the impact of profitability of both individual companies and the industry as a whole.

In particular, the results obtained during the application of the expert method (in contrast to the methods of comparative analysis used in $[7,17,24]$ showed that the impact of increased costs of creating an effective personal data protection system in the company, as a consequence of the implementation of legislation, have a direct impact on the dynamics of profitability of companies operating in the fields listed in the International Classification of Economic Activities (NACE).

When analyzing the relationship between the spread of personal data protection practices and the profitability of companies, it was the first time when the attention was paid to the impact of such a factor as "Increased cost of personal data protection due to the tightening of legislation in this area", extending the research by [43].

Despite the close attention to the subject, scholars do not cover issues related to the creation of the necessary institutional prerequisites for the spread of personal data protection in developing economies, as well as guidelines for assessing these national prerequisites. The latter, in fact, should be the object of further study. The analysis and comparison of the obtained results with world analogues and scientific developments proves their novelty [44-46].
The task of the state policy of personal data protection is to create institutions that would be the main regulators of personal data circulation. Responsibility for misuse and dissemination of information containing personal data needs to be strengthened. This will not only create a secure information space for citizens, but also increase the country's investment attractiveness. Thus, the study proved the initial hypothesis that the main factor influencing the level of development of companies in the context of spreading personal data protection systems is the underdeveloped institutional environment for the regulation of this area.

\section{Conclusion}

The relevance of the topic of the article is due to the active penetration of digital technologies in all spheres of modern society. The business community and governments of the world, including Ukraine, are aware of the need to accelerate the processes of digitalization and digital transformation of the economy in order to achieve competitive positions.

The issue of personal data protection, incurring costs for the development of the data protection system is urgent, especially in the context of the spread of digitalization processes to all spheres of life. Besides the existing benefits, this also causes hidden problematic aspects, including a decreased customer confidence in the company's activities and other groups of stakeholders in terms of data security. Thus, the problem of personal data protection involves other consequences of today's widespread access to personal information of people in the context of digitalization.

Increasing trust in the personal data use is a prerequisite for the full realization of the benefits of companies' digital transformation. This, in turn, requires policy makers to better understand and take into account data heterogeneity, apply a strategic approach to data management and ensure that all policy objectives are taken into account, as well as improve their ability to use data to better policymaking.

Practice shows that the most common types of personal databases of Ukrainian companies are employee databases and databases of customers or contractors. The reports with information about individuals that were part of the databases are not subject to registration as an object of personal databases.

The obtained average value of expert assessments for such a factor of the macroenvironment as "Increased cost of personal data protection due to the tightening of legislation in 
this area" is +2 . That is, according to most experts, the relevant factor has a direct impact on changing the company's profitability of moderate importance for the industry and the degree of influence.

The obtained results are a contribution to scientific achievements in the field of personal data protection and business development. This is primarily due to the novel research objectives.

The practical value of the obtained scientific results is the analysis of scientific approaches and policy frameworks issued by international organizations, as well as the expert assessment of the impact of political and legal factors on the companies' profitability. The results obtained in this work can serve as a methodological basis for further sectoral research in order to assess the impact of the requirements of the institutional environment on the companies engaged in various economic activities.

Based on the data obtained, it is necessary to recommend companies to deepen cooperation in the field of data protection. It is necessary to study the experience of major players in the IT market and implement successful business solutions to protect customer data. Also a necessary condition for improving the investment attractiveness of the company is the implementation of international protocols in the field of personal data protection. Further research may be aimed at studying the effectiveness of the implementation of international protocols in the production processes of domestic IT companies.

\section{References:}

[1] United Nations, The Right to Privacy in the Digital Age, New York: United Nations Publications, 2014.

[2] Aladwani, A. M., and Dwivedi, Y. K., Towards a Theory of Socio Citizenry: Quality Anticipation, Trust Configuration, and Approved Adaptation of Governmental Social Media, International Journal of Information Management, Vol. 43, 2018. pp. 261-272.

[3] Alrifai, R., A Data Mining Approach to Evaluate Stock-Picking Strategies, Journal of Computing Sciences in Colleges, Vol. 32, No. 5, 2017, pp. 148-155.

[4] Ballestar, M. T., Grau-Carles, P., and Sainz, J., Customer Segmentation in E-Commerce: Applications to the Cashback Business Model, Journal of Business Research, Vol. 88, 2018, pp. 407-414.

[5] Beaput, S., Banik, D., and Joshi, D., Ranking Privacy of the Users in the Cyberspace, The Journal of Computing
Sciences in Colleges, Vol. 35, No. 4, 2019, pp. 109-114.

[6] Guinan, P.J., Parise, S., and Langowitz, N., Creating an Innovative Digital Project Team: Levers to Enable Digital Transformation, Business Horizons, Vol. 62, No. 6, 2019, pp. 717-727.

[7] Natorina, A., Business Optimization in the Digital Age: Insights and Recommendations, Economic Annals-XXI, Vol. 181, No. 1-2, 2020, pp. 83-91.

[8] Polozhentseva, Y., Klevtsova, M., and Leontyev, E., Effects of the Economic Space Digitalization in the Context of Modern Society Transformation, Economic Annals-XXI, Vol. 180, No. 11-12, 2019, pp.78-87.

[9] Victor, V., Thoppan, J.J., Fekete-Farkas, M., and Grabara, J., Pricing Strategies in the Era of Digitalisation and the Perceived Shift in Consumer Behaviour of Youth in Poland, Journal of International Studies, Vol. 12, No. 3, 2019, pp. 74-91.

[10] Brous, P., Janssen, M., and Herder, P., The Dual Effects of the Internet of Things (IoT): A Systematic Review of the Benefits and Risks of IoT Adoption by Organizations, International Journal of Information Management, Vol. 51, 2020, p. 101952.

[11] Caseiro, N. and Coelho, A., The Influence of Business Intelligence Capacity, Network Learning and Innovativeness on Startups Performance, Journal of Innovation and Knowledge, Vol. 4, No. 3, 2019, pp. 139-145.

[12] Cheng, F.C., and Wang, Y.S., The Do Not Track Mechanism for Digital Footprint Privacy Protection In Marketing Applications, Journal of Business Economics and Management, Vol. 19, No. 2, 2018, pp. 253-267.

[13] Dadzie, A.S., Sibarani, E.M., Novalija, I., and Scerri, S., Structuring Visual Exploratory Analysis of Skill Demand, Journal of Web Semantics, Vol. 49, 2018, pp. 51-70.

[14] De Caigny, A., Coussement, K., and De Bock, K.W., Leveraging Fine-Grained Transaction Data for Customer Life Event Predictions, Decision Support Systems, Vol. 130, 2020, p. 113232.

[15] Devece, M., Ribeiro-Soriano, D.E., and Palacios-Marqués, D., Coopetition as the New Trend in Inter-Firm Alliances: Literature Review and Research Patterns, Review of Managerial Science, Vol. 13, No.2, 2019, pp. 207-226.

[16] Hodge, V. J., Sephton, N., Devlin, S., Cowling, P. I., Goumagias, N., Shao, J.,.... and 
Li, F, How the Business Model of Customisable Card Games Influences Player Engagement, IEEE Transactions on Games, Vol. 11, No. 4, 2018, 374-385.

[17] Melnyk, L., Dehtyarova, I., Kubatko, O., Karintseva, O., and Derykolenko, A., Disruptive Technologies for the Transition of Digital Economies Towards Sustainability, Economic Annals-XXI, Vol. 179, No. 9-10, 2019, pp. 22-30.

[18] Pecheranskyi, I., and Revenko, A., Disruptive Digital Technologies as a Means for Destroying the Foundations of Oligarchomics: World Experience and Challenges for Ukraine, Economic Annals-XXI, Vol. 179, No. 9-10, 2019, pp. 31-39.

[19] Popova, N., Kataiev, A., Skrynkovskyy, R., and Nevertii, A., Development of Trust Marketing in the Digital Society, Economic Annals-XXI, Vol. 176, No. 3-4, 2019, pp. 1325.

[20] Tleppayev, A. Digitalisation and Energy: World Experience and Evidence of Correlation from Kazakhstan, Economic Annals-XXI, Vol. 176, No. 3-4, 2019, pp. 56-64.

[21] Dremel, C., Herterich, M.M., Wulf, J., and Vom Brocke, J., Actualizing Big Data Analytics Affordances: A Revelatory Case Study, Information and Management, Vol. 57, No. 1, 2020, pp. 103-121.

[22] Janssen, M., Brous, P., Estevez, E., Barbosa, L.S., and Janowski, T., Data Governance: Organizing Data for Trustworthy Artificial Intelligence, Government Information Quarterly, Vol. 37, No. 3, 2020, pp. 101-493.

[23] Line, N.D., Dogru, T., El-Manstrly, D., Buoye, A., Malthouse, E., and Kandampully, J., Control, Use and Ownership of big Data: A Reciprocal View of Customer Big Data Value in the Hospitality and Tourism Industry, Tourism Management, Vol. 80, 2020, pp. 104106.

[24] Mexmonov, S., Actual Issues of Electronic Commerce Development in the Republic of Uzbekistan, Virtual Open Day for International Students, Vol. 33, No. 1, 2020, Art. 33.

[25] Petrenko, E.S., and Shevyakova, A.L., Features and Perspectives of Digitization in Kazakhstan, In: E. Popkova (Ed.), Ubiquitous Computing and the Internet of Things: Prerequisites for the Development of ICT. Studies in Computational Intelligence (vol. 826), Springer, 2019.

[26] Strategic Policy Forum on Digital Entrepreneurship, Accelerating the Digital
Transformation of European Industry and Enterprises, European Commission, 2016.

[27] Budanov, V., and Aseeva, I., Manipulative Marketing Technologies in New Digital Reality, Economic Annals-XXI, Vol. 180, No. 11-12, 2019, pp. 58-68.

[28] Trusova, N., Government Socio-Economic Policy under the Digital Economy in the Foreign Countries and Russia, Economic Annals-XXI, Vol. 180, No. 11-12, 2019, pp. 8896.

[29] Mayakova, A, Digital Transformation of Modern Quality Management, Economic Annals-XXI, Vol. 180, No. 11-12, 2019, pp. 138-145.

[30] Kuznetsova, I.G., Goloshchapova, L.V., Ivashina, N.S., Shichiyakh, R.A., Petrova, L.I., and Tkachev, B.P., The Paradigm of Human Capital Development Capable of Adapting Innovations In the Transition to a Digital Economy, International Journal of Civil Engineering and Technology, Vol. 10, No. 2, 2019, pp. 1408-1417.

[31] Bilozubenko, V., Yatchuk, O., Wolanin, E., Serediuk, T., and Korneyev, M. Comparison of the Digital Economy Development Parameters in the EU Countries in the Context of Bridging the Digital Divide. Problems and Perspectives in Management, Vol. 18, No. 2, 2020, pp. 206218.

[32] Shen, C.W., Luong, T.H., Ho, J.T., and Djailani, I., Social Media Marketing of IT Service Companies: Analysis Using a ConceptLinking Mining Approach, Industrial Marketing Management, Vol. 90, 2020, pp. 593-604.

[33] Hung, J.-L., He, W., and Shen, J., Big Data Analytics for Supply Chain Relationship in Banking, Industrial Marketing Management, Vol. 86, 2020, pp. 144-153.

[34] Ungureanu, C.T., Legal Remedies for Personal Data Protection in European Union, Logos, Universality, Mentality, Education, Novelty, Section: Law, Vol. 6, No. 2, 2018, pp. 26-47.

[35] African Commission on Human and Peoples' Rights, Model Law on Access to Information for Africa 2013, 2013. Available online at: https://www.achpr.org/legalinstruments/detail?i $\mathrm{d}=32$

[36] African Commission on Human and Peoples' Rights, 362 resolution on the right to freedom of information and expression on the Internet in Africa - ACHPR/Res. 362 (LIX) 
2016, 2016. Available online at: https://www.achpr.org/sessions/resolutions?id= 374

[37] African Commission on Human and Peoples' Rights, Declaration of Principles on Freedom of Expression in Africa, 2019. Available online at: https://www.achpr.org/public/Document/file/E nglish/draft_declaration_of_principles_on_free dom_of_expression_in_africa_eng.pdf

[38] General Data Protection Regulation, n.d. Online available at: https://www.cookiebot.com/en/gdpr/

[39] Verkhovna Rada of Ukraine, The Law of Ukraine “On Personal Data Protection”, 2010. Online available at: https://zakon.rada.gov.ua/laws/show/229717\#Text

[40] United Nations, Digital Economy Report 2019. Value Creation and Capture Implications for Developing Countries, New York: United Nations Publications, 2019.

[41] OECD, Data in the Digital Age, 2019. Available online at: https://www.oecd.org/going-digital/data-in-thedigital-age.pdf

[42] OECD, Exploring the Economics of Personal Data: A Survey of Methodologies for Measuring Monetary Value, OECD Digital Economy Papers, 220, OECD, 2013.

[43] Stjepić, A.M., Ivančić, L., and Vugec, D.S., Mastering Digital Transformation through Business Process Management: Investigating Alignments, Goals, Orchestration, and Roles, Journal of Entrepreneurship, Management and Innovation, Vol. 16, No. 1, 2019, pp. 64-80.

[44] OECD, Glossary of Statistical Terms, 2020. Available online at: https://stats.oecd.org/glossary/detail.asp?ID $=30$ 3

[45] State Statistics Service of Ukraine, Financial Results before Taxation of Enterprises by Type of Economic Activity with Division into Large, Medium, Small and Micro Enterprises, 2020. Available online at: http://www.ukrstat.gov.ua/operativ/operativ201 8/fin/fin_new/fin_new_u/arh_fr_roz_ed_u.htm

[46] Tafazolli, R., Chatzimisios P., and Wang, C.L. (Eds.), Wiley 5G Ref: The Essential 5G Reference Online, New York: John Wiley \& Sons, 2020.

\section{Contribution of Individual Authors to the Creation of a Scientific Article (Ghostwriting Policy)}

All the authors contributed equally in the development of the present paper. All of the phases of the paper development proper have been discussed and worked on by the authors. All authors have read and agreed to the published version of the manuscript.

\section{Creative Commons Attribution License 4.0 (Attribution 4.0 International, CC BY 4.0)}

This article is published under the terms of the Creative Commons Attribution License 4.0 https://creativecommons.org/licenses/by/4.0/deed.en US 